\title{
The role of neurosteroids in the pathogenesis of hepatic encephalopathy
}

\section{Uloga neurosteroida u patogenezi heapatične encefalopatije}

\section{Dušan Mladenović ${ }^{1}$, Olivera Stanojlović2 ${ }^{\text {, Tatjana Radosavljević }}{ }^{1}$}

${ }^{1}$ Institut za patološku fiziologiju, Medicinski fakultet, Univerzitet u Beogradu

${ }^{2}$ Institut za medicinsku fiziologiju „Rihard Burijan“, Univerzitet u Beogradu

Kontakt:dmladen@med.bg.ac.rs

Sažetak

Hepatična encefalopatija (HE) predstavlja neuropsihijatrijski sindrom uzrokovan akutnom ili hroničnom insuficijencijom jetre. Glavnu ulogu u patogenezi HE ima hiperamonijemija. Mehanizmi kojima amonijak izaziva razvoj HE su poremećaji neurotransmisije, oksidativni stres, neuroinflamacija, mitohondrijska disfunkcija i energetski deficit. Neurosteroidi značajno doprinose povećanoj GABA-ergičkoj aktivnosti u HE. Amonijak u kombinaciji sa manganom i proinflamatornim citokinima stimuliše sintezu neurosteroida ushodnom regulacijom translokatorskog proteina, komponentom multiproteinskog kompleksa koja stimuliše transport holesterola $\mathrm{u}$ mitohondrije astrocita. Holesterol služi kao supstrat za sintezu neurosteroida alopregnanolona i tetrahidrodeoksikortikosterona. Nakon oslobađanja iz astrocita alopregnanolon i tetrahidrodeoksikortikosteron pojačavaju GABA-ergičku transmisiju pozitivnom alosternom modulacijom GABAA receptora, čime doprinose poremećajima ciklusa budnost-spavanje i kognitivnim poremećajima u HE. Dodatni potencijalni mehanizmi dejstva neurosteroida u HE uključuju modulaciju aktivnosti serotoninergičkih, holinergičkih, glicinergičkih, glutamatergičkih i opioidnih receptora, kao i modulaciju genske ekspresije. Cilj ovog preglednog rada je bio da prikaže dosadašnja saznanja o ulozi neurosteroida u patogenezi HE.

Ključne reči: neurosteroidi, hepatična encefalopatija, amonijak, neurotransmisija

\section{Introduction}

Hepatic Encephalopathy (HE) represents a complex neuropsychiatric syndrome caused by acute or chronic liver failure (1). It may be presented in three major forms: type A (caused by acute liver failure), type B (caused by porto-systemic shunt without liver disease), and type C HE (associated with liver cirrhosis) (2). Type A $\mathrm{HE}$ has a rapid course with deterioration of mental functions, convulsions and the loss of conciousness. On
Abstract

Hepatic Encephalopathy (HE) represents a neuropsychiatric syndrome caused by acute or chronic liver failure. Hyperammonemia plays a pivotal role in the development of $\mathrm{HE}$ through modulation of neurotransmission, oxidative stress, neuroinflammation, mitochondrial dysfunction, and energy deficit. Neurosteroids contribute significantly to increased GABAergic tone in HE. Ammonia, in combination with manganese and proinflammatory cytokines, stimulate neurosteroid synthesis by up-regulation of translocator protein, a component of multiprotein complex that stimulate cholesterol transport into astrocytic mitochondria. Cholesterol serves as a substrate for the synthesis of neurosteroids allopregnanolone and tetrahydro-deoxycorticosterone. After release from astrocytes, allopregnanolone and tetrahydro-deoxycorticosterone potentiate GABAergic transmission by positive allosteric modulation of GABAA receptor, thus contributing to cognitive deficit and alterations in sleep-wake cycle. Additional potential mechanisms of neurosteroid action in HE include modulation of serotoninergic, cholinergic, glutamatergic, glycinergic, and opioid receptor activities, as well as modulation of gene expression. This review aimed to summarize current knowledge of the role of neurosteroids in the pathogenesis of HE.

Key words: neurosteroids, hepatic encephalopathy, ammonia, neurotransmission

the other hand, signs and symptoms of chronic HE (usually type C) may vary from subtle cognitive dysfunction and attention deficits, which cannot be detected by the standard neurological exam (minimal HE), to the development of hepatic coma in the stage 4 of $\mathrm{HE}(2,3)$.

The pathogenesis of HE is complex and not fully established. In type A HE hyperammonemia, along with other toxins, induces cytotoxic brain edema due to the swelling of astrocytes, with subsequent rise in intracranial pressure (4). This may potentially lead to the fatal outcome due to the brainstem herniation in the foramen magnum. 
Opposite to the acute form, type B and type C HE are not characterized by prominent brain edema, but the dominant pathological change is Alzheimer type II astrocytosis (large pale nuclei with prominent nucleoli frequently occuring in pairs, cytoplasmic vacuolization), found in both grey and white matter $(5,6)$. Pathogenetic mechanisms involved in the development of chronic forms of $\mathrm{HE}$ are closely interrelated and include: alterations in neurotransmission (7), oxidative stress $(8,9)$, energy deficit (10), neuroinflammation (11) and mitochondrial dysfunction $(12,13)$. Alterations in neurotransmission have an important role in the pathogenesis of types $\mathrm{B}$ and $\mathrm{C} \mathrm{HE}$ and include changes in glutamatergic (14), GABAergic (14), cholinergic $(15,16)$, serotoninergic (17), dopaminergic (18), adrenergic (19) and purinergic transmission (20). Neurosteroids contribute significantly to changes in neurotransmission found in HE. This review aimed to summarize current knowledge of the role of neurosteroids in the pathogenesis of HE.

\section{Synthesis of neurosteroids}

Neurosteroids have been initially defined as steroid compounds synthesized within brain, that remain elevat- ed in the central nervous system after ablation of peripheral sources (21). They may be classified, according to the structural features, into three major groups: pregnane neurosteroids (allopregnanolone, tetrahydro-deoxy-corticosterone), androstane neurosteroids (androstanediol, etiocholanolone) and sulphated neurosteroids (pregnenolone sulphate, dehydroepiandrosterone sulphate) $(22,23)$. The initial step in neurosteroid synthesis includes the transport of cholesterol into the mitochondria, by the action of Translocator protein (TSPO) formerly known as Peripheral-type benzodiazepine receptor. TSPO associates with Voltage-dependent anion channel (VDAC) and Adenine nucleotide carrier (ANC) to form a heteromeric complex on outer mitochondrial membrane, which allows the transfer of cholesterol through the hydrophilic intermembrane space (24). After transfer cytochrome P450 cholesterol side chain cleavage enzyme (P450scc) catalyzes the conversion of cholesterol to pregnenolone, a rate-limiting step in neurosteroid synthesis. Pregnenolone is further converted to progesterone, Allopregnanolone (ALLO) and Tetrahydro-deoxy-corticosterone (THDOC) in series of enzymatic reactions, which occur in the smooth endoplasmic reticulum and mitochondria $(24,25)$ (figure 1).

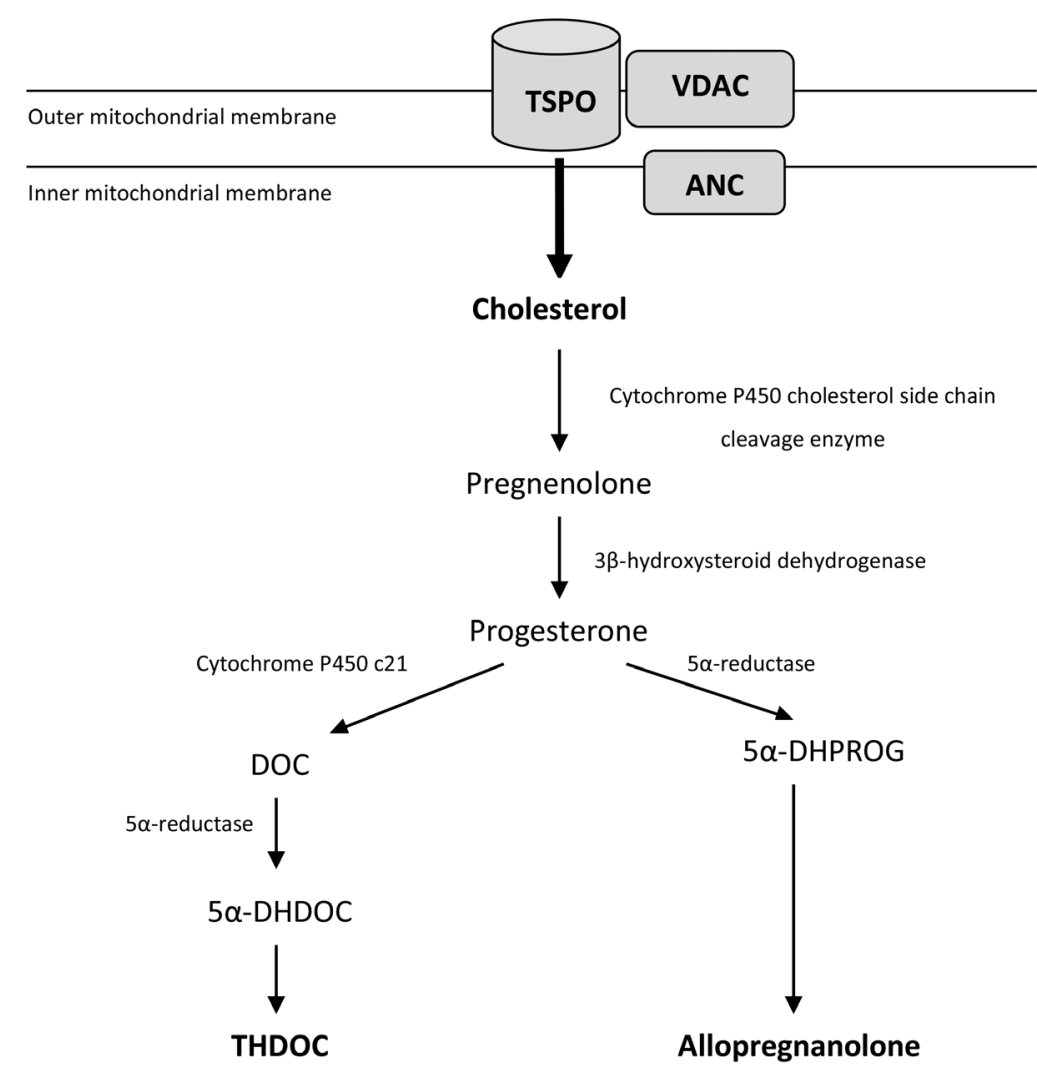

Figure 1. Synthesis of neurosteroids in astrocytes. Neurosteroidogenesis starts with uptake of cholesterol into astrocytic mitochondria mediated by TSPO. Cholesterol is then converted to neurosteroids through a series of enzymatic reactions (TSPO, Translocator protein; VDAC, Voltage-dependent anion channel; ANC, Adenine nucleotide carrier; DOC, Deoxycorticosterone; 5a-DHDOC, 5a-dihydrodeoxycorticosterone; THDOC, Tetrahydro-deoxycortico-sterone; $5 a$-DHPROG, 5a-dihydro-progesterone) (modified according to Ahboucha et al.)(24). 
Neurosteroids were found to exhibit some fundamental effects on the myelination, synaptic organization (26-28). They participate in the regulation of food intake, sexual behavior, anxiety, body temperature, blood pressure (29) and may also exert neuroprotective effects in Parkinson's disease, Alzheimer's disease, epilepsy and stroke (23).

\section{Neurosteroids and HE}

The involvement of neurosteroids in the pathogenesis of HE was first suggested by Zaman (30), as an alternative to the hypothesis that "endogenous benzodiazepines, mediate increased GABAergic tone in HE. In accordance with the supposed role of neurosteroids in $\mathrm{HE}$, later studies have confirmed the increased brain level of pregnenolone, ALLO and THDOC in experimental models of HE induced by thioacetamide, (TAA) (31) together with liver ischemia caused by portacaval anastomosis (PCA) and hepatic artery ligation (24). An increase in pregnenolone and ALLO was also found in autopsied brain tissue from cirrhotic patients who died in hepatic coma (32). Ahboucha et al. (24) have demonstrated that brain levels of neurosteroids correlate with the severity of HE. Furthermore, the blockage of neurosteroid synthesis by finasteride, $5 \alpha$-reductase inhibitor, was found to improve the course of TAA-induced HE and to reduce mortality in rats (33). Finasteride pretreatment ameliorates motor activity, preserves vital reflexes and completely prevents the development of hepatic coma. Motor changes are followed by both an increase in mean voltage of EEG bands and a decrease in delta band proportion in total power density. All findings correspond to mild stages of HE $(33,34)$. Together, these findings point out the significant role of neurosteroids in the pathogenesis of HE.

Various studies $(24,35-37)$ have shown that neurosteroid levels in HE are elevated due to increased neurosteroid synthesis consistently, partly caused by the up-regulation of TSPO on astrocytic mitochondrial membrane. This was, firstly demonstrated by Itzhak et al. (35), who have found increased binding site densities of the isoquinoline ligand [3H]PK11195 and the peripheral benzodiazepine ligand $[3 \mathrm{H}] \mathrm{Ro5}-4864$ in brains of TAA-treated mice. TSPO expression was found to be increased in a region-selective manner in the PCA model of HE, with the highest increase in the cerebellum and pons, with the lowest increase in the striatum $(38,39)$. Region-selective up-regulation of TSPO was also found in humans with different etiologies of cirrhosis, but with highest increase in right dorsolateral prefrontal cortex, pallidum and putamen (40). Increased TSPO expression in the brain is mediated by hyperammonemia in combination with proinflammatory cytokines (IL- $1 \beta$, TNF- $\alpha$ ) in acute, and manganese in chronic forms of HE (24). This is evident by increased densities of [3H]PK11195 or [3H]Ro5-4846 binding sites in all experimental models $(35,38)$, as well as in human HE (40), whenever hyperammonemia develops. Similar changes occur after treatment of cultured astrocytes with pathophysiologically relevant concentrations of manganese (41) and proinflammatory cytokines $(24,42)$.

Apart from the up-regulation of TSPO, increased neurosteroid synthesis in HE may be also mediated by increased blood-brain transfer of lipophylic neuroactive steroids (43). Activation of TSPO, by its "endogenous ligands" such as diazepam binding inhibitor and its processing product octadecaneuropeptide, have also been postulated to stimulate neurosteroid synthesis (44). Both peptide levels were found to be elevated in the cerebrospinal fluid of HE patients (45) and in brain extracts from animals models of HE (46). Peripheral sources of neurosteroids may also contribute to the pathogenesis of HE (44). Although these additional mechanisms cannot be excluded, the majority of data suggest that the up-regulation of TSPO by hyperammonemia and other toxins plays a pivotal role in the increased synthesis of neurosteroids in HE.

Mechanisms of neurosteroid action in HE include modulation of various membrane receptor activities, including GABAA, N-methyl-D-aspartate (NMDA), and serotoninergic receptors (nongenomic effects), as well as the modulation of intracellular receptor activities, which can regulate gene expression (genomic effects) $(14,24)$. Additionally, neurosteroids may modulate brain oxidative stress and neuroinflammation in $\operatorname{HE}(16,24,33)$.

\section{Neurosteroids and GABAergic transmission}

The effects of neurosteroids on GABAergic transmission have been most extensively studied. Earlier studies postulated that "endogenous benzodiazepines" modulate GABAergic transmission in HE (47), thus suggesting that administration of flumazenil, benzodiazepine site antagonist, may have beneficial effects in HE (48). However, the role of "endogenous benzodiazepines" has been seriously questioned, since neuroprotective effect of flumazenil in HE was not consistent (24). Further opposing the role of benzodiazepine-like ligands in alterations of GABAergic transmission was the fact that "endogenous benzodiazepines, were not elevated in the plasma, brain and cerebrospinal fluid of HE patients (49). These findings shed light on neurosteroids as potential mediators of changes in GABAergic transmission in HE. It is known that ALLO and THDOC bind to a specific neurosteroid site on GABAA receptor and potentiate GABAergic transmission in $\mathrm{HE}$, as positive allosteric modulators of GABAA receptors $(39,50)$. Radiometric assays in autopsied brain tissue, from cirrhotic patients who died 
in hepatic coma, have shown that neurosteroids do not change neither GABA nor benzodiazepine recognition sites, they just modulate both sites on GABAA receptor complex $(39,51)$. The interaction between neurosteroids and benzodiazepine binding site has been further confirmed by consistently beneficial effects of Ro15-4513, benzodiazepine partial inverse agonist, on the course of HE. Ro15-4513 reduces the modulatory activity of neurosteroids and attenuates the effects of ALLO on GABA-induced chloride currents in hippocampal neurons (52). Neurosteroids also act in synergy with ammonia at the benzodiazepine site, evident as a dose-dependent ALLO-induced increase in the binding of $(3 \mathrm{H})$ flumazenil in the presence of ammonia (39).

Recent studies revealed a reduced synthesis of dehydroepiandrosterone sulphate (DHEAS), negative allosteric modulator of GABAA receptor, in HE (53). In summary, increased synthesis of ALLO and THDOC, positive allosteric modulators and reduced synthesis of DHEAS, negative allosteric modulator of GABAA receptor, potentiate GABAergic transmission and contribute to the cognitive dysfunction and alterations in sleepwake cycle in HE (14).

\section{Other potentially relevant effects of neurosteroids in $\mathrm{HE}$}

It is known that neurosteroids apart from GABAA affect the function of various receptors in the brain, including serotonin 5-HT3 receptors, NMDA receptors, glycine receptors and opioid receptors (54). However, the relevance of these effects in the pathogenesis of HE has not been fully established. Interactions between neurosteroids and serotoninergic transmission have been most studied. It is suggested that HE is accompanied with increased serotoninergic transmission, based on an improvement of $\mathrm{HE}$ after administration of nonselective serotonin antagonist methysergide (55) and selective 5-HT3 receptor antagonist ondansetron (17). Furthermore, administration of venlafaxine, serotonin reuptake inhibitor, worsens HE and increases serotonin concentration in synaptic clefts in PCA rats (56). This increase is associated with increased level of ALLO (57), thus suggesting that neurosteroids may be involved in the modulation of serotoninergic transmission in HE.

Neurosteroids may also modulate cholinergic transmission in HE, in a region-selective manner. Acetylcholinesterase activity was found to rise in the thalamus and caudate nucleus in TAA-induced HE in rats, the effect that can be impeded by finasteride, neurosteroid synthesis inhibitor (16). The contribution of this effect to motor and cognitive changes in HE should be further investigated.
$\mathrm{HE}$ is associated with altered expression of several key astrocytic and neuronal proteins, including Glial fibrillary acidic protein (GFAP), aquaporin IV, transporters for glucose (GLUT1), glycine (GLYT-1) and glutamate (EAAT-2), as well as enzymes Monoaminooxidase A (MAO-A) and nitric oxide synthase $(39,58)$. Although the role of neurosteroids in regulating the expression of these proteins is still blurred, it is clear that neurosteroids could change the expression of several genes (genomic effects). Progesterone, its metabolites and possibly other neurosteroids bind to progesterone or pregnane X receptors and change the expression of GFAP and aquaporin IV. Additionally, GLUT-1 and MAO-A gene expression may be altered by activation of glucocorticoid receptors (24). Genomic effects of neurosteroids have been postulated to contribute to astrocyte swelling in HE (59). However, this hypothesis remains controversial, since ALLO and progesterone were found to reduce brain edema in other pathological states, such as traumatic brain injury $(24,60)$.

Neurosteroids may have a dual region-specific role in oxidative brain injury in HE (16). While finasteride pretreatment reduces lipid peroxidation in the cerebral cortex, it increases oxidative lipid damage in the thalamus in TAA-induced liver failure. Prooxidative effect of neurosteroids in the cortex could be mediated by reduced catalase activity (16). The significance of these effects in the pathogenesis of HE should be further investigated.

\section{Conclusion}

Neurosteroids play an important role in the pathogenesis of HE. Hyperammonemia, manganese and proinflammatory cytokines up-regulate TSPO in outer mitochondrial membrane of astrocytes, thus enabling increased cholesterol uptake into mitochondria. Cholesetrol serves as a substrate for the synthesis of neurosteroids, which are then released from astrocytes and exert nongenomic and genomic effects in neurons. Among these effects, the most important seems to be the modulation of GABAergic transmission. ALLO and THDOC, as positive allosteric modulators of GABAA receptors, potentiate GABAregic transmission and contribute to cognitive dysfunction and alterations in sleep-wake cycle in HE $(14,24,39,44)$. Additionally, neurosteroids modulate the activity of serotonin, glycine, glutamate, opioid receptors, as well as the expression of key neuronal and astrocytic genes $(39,54,58)$, but the contribution of these effects to the pathogenesis of HE should be further investigated. Inhibitors of neurosteroid synthesis $(16,33)$ or neurosteroid site antagonists at GABAA receptor (44) could have beneficial effects on the course of HE. 


\section{References}

1. Gammal SH, Jones EA. Hepatic encephalopathy. Med Clin North Am 1989; 73:793-813.

2. Ferenci P, Lockwood A, Mullen K, Tarter R, Weissenborn K, Blei AT. Hepatic encephalopathy--definition, nomenclature, diagnosis, and quantification: final report of the working party at the 11th World Congresses of Gastroenterology, Vienna, 1998. Hepatology 2002; 35:716-21.

3. Córdoba J. New assessment of hepatic encephalopathy. J Hepatol 2011; 54:1030-40.

4. Shawcross D, Jalan R. The pathophysiologic basis of hepatic encephalopathy: central role for ammonia and inflammation. Cell Mol Life Sci 2005; 62:2295-304.

5. Butterworth RF. Altered glial-neuronal crosstalk: cornerstone in the pathogenesis of hepatic encephalopathy. Neurochem Inter 2010; 57:383-8.

6. Norenberg MD. The role of astrocytes in hepatic encephalopathy. Neurochem Pathol 1987; 6:13-33

7. Palomero-Gallagher N, Bidmon H-J, Cremer M, Schleicher A, Kircheis G, Reifenberger G, et al. Neurotransmitter receptor imbalances in motor cortex and basal ganglia in hepatic encephalopathy. Cell Physiol Biochem 2009; 24:291-306.

8. Görg B, Schliess F, Häussinger D. Osmotic and oxidative/ nitrosative stress in ammonia toxicity and hepatic encephalopathy. Arch Biochem Biophys 2013; 536:158-63.

9. Mladenović D, Krstić D, Colović M, Radosavljević T, Rasić-Marković A, Hrncić D, Macut D, Stanojlović O. Different sensitivity of various brain structures to thioacetamide-induced lipid peroxidation. Med Chem. 2012; 8:52-8.

10. Hertz L, Kala G. Energy metabolism in brain cells: effects of elevated ammonia concentrations. Metab Brain Dis 2007; 22:199-218.

11. Butterworth RF. Hepatic encephalopathy: a central neuroinflammatory disorder? Hepatology 2011; 53:1372-6.

12. Bernardi P. The permeability transition pore. Control points of a cyclosporin A-sensitive mitochondrial channel involved in cell death. Biochim Biophys Acta 1996; 1275:5-9.

13. Bustamante J, Lores-Arnaiz S, Tallis S, Roselló DM, Lago N, Lemberg A, et al. Mitochondrial dysfunction as a mediator of hippocampal apoptosis in a model of hepatic encephalopathy. Mol Cell Biochem 2011; 354:231-40.

14. Cauli O, Rodrigo R, Llansola M, Montoliu C, Monfort P, Piedrafita B, et al. Glutamatergic and gabaergic neurotransmission and neuronal circuits in hepatic encephalopathy. Metab Brain Dis 2009; 24:69-80.

15. García-Ayllón M-S, Cauli O, Silveyra M-X, Rodrigo R, Candela A, Compañ A, et al. Brain cholinergic impairment in liver failure. Brain 2008; 131(Pt 11):2946-56.

16. Mladenović D, Petronijević N, Stojković T, Velimirović M, Jevtić G, Hrnčić D, et al. Finasteride has regionally different effects on brain oxidative stress and acetylcholinesterase activity in acute thioacetamide-induced hepatic encephalopathy in rats. PLoS One 2015; 10:e0134434.
17. Piche T, Vanbiervliet G, Cherikh F, Antoun Z, Huet PM, Gelsi E, et al. Effect of ondansetron, a 5-HT3 receptor antagonist, on fatigue in chronic hepatitis C: a randomised, double blind, placebo controlled study. Gut 2005; 54:116973.

18. Mousseau DD, Perney P, Layrargues GP, Butterworth RF: Selective loss of pallidal dopamine D2 receptor density in hepatic encephalopathy. Neurosci Lett 1993; 162:192-6.

19. Michalak A, Rose C, Buu PN, Butterworth RF. Evidence for altered central noradrenergic function in experimental acute liver failure in the rat. Hepatology 1998; 27:362-8.

20. Boy C, Meyer PT, Kircheis G, Holschbach MH, Herzog $\mathrm{H}$, Elmenhorst D, et al. Cerebral A1 adenosine receptors (A1AR) in liver cirrhosis. Eur J Nucl Med Mol Imaging 2008; 35:589-97.

21. Baulieu EE. Neurosteroids: a novel function of the brain. Psychoneuroendocrinology 1998; 23:963-87.

22. Reddy DS. Neurosteroids: endogenous role in the human brain and therapeutic potentials. Prog Brain Res 2010; 186:113-37.

23. Rahmani B, Ghasemi R, Dargahi L, Ahmadiani A, Haeri A. Neurosteroids; potential underpinning roles in maintaining homeostasis. Gen Comp Endocrinol 2016; 225:242-50.

24. Ahboucha S, Gamrani H, Baker G. GABAergic neurosteroids: the "endogenous benzodiazepines" of acute liver failure. Neurochem Inter 2012; 60:707-14.

25. Hu J, Zhang Z, Shen WJ, Azhar S. Cellular cholesterol delivery, intracellular processing and utilization for biosynthesis of steroid hormones. Nutr Metab (London) 2010; $1: 47$.

26. Baulieu E, Schumacher M. Progesterone as a neuroactive neurosteroid, with special reference to the effect of progesterone on myelination. Steroids 2000; 65:605-12.

27. Garcia-Segura LM, Melcangi RC. Steroids and glial cell function. Glia 2006; 54:485-98.

28. Peper JS, van den Heuvel MP, Mandl RC, Hulshoff Pol HE, van Honk J. Sex steroids and connectivity in the human brain: a review of neuroimaging studies. Psychoneuroendocrinology 2011; 36:1101-13.

29. Do Rego JL, Seong JY, Burel D, Leprince J, Luu-The V, Tsutsui K, et al. Neurosteroid biosynthesis: enzymatic pathways and neuroendocrine regulation by neurotransmitters and neuropeptides. Front Neuroendocrinol 2009; 30:259-301.

30. Zaman SH. Endogenous steroids and pathogenesis of hepatic encephalopathy. Lancet 1990; 336:573-4.

31. Norenberg MD, Itzhak Y, Bender AS. The peripheral benzodiazepine receptor and neurosteroids in hepatic encephalopathy. Adv Exp Med Biol 1997; 420:95-111.

32. Ahboucha S, Pomier-Layrargues G, Mamer O, Butterworth RF. Increased levels of pregnenolone and its neuroactive metabolite allopregnanolone in autopsied brain tissue from cirrhotic patients who died in hepatic coma. Neurochem Int 2006; 49:372-8.

33. Mladenović D, Hrnčić D, Petronijević N, Jevtić G, Radosavljević T, Rašić-Marković A, et al. Finasteride improves motor, EEG, and cellular changes in rat brain in thioacetamide-induced hepatic encephalopathy. Am J Physiol Gastrointest Liver Physiol 2014; 307:G931-40. 
34. Mladenović D, Radosavljević T, Hrnčić D, Rašić-Marković A, Puškaš N, Maksić N, et al. Behavioral and electroencephalographic manifestations of thioacetamide-induced encephalopathy in rats. Can J Physiol Pharmacol 2012; 90:1219-27.

35. Itzhak Y, Roig-Cantisano A, Dombro RS, Norenberg MD. Acute liver failure and hyperammonemia increase peripheral-type benzodiazepine receptor binding and pregnenolone synthesis in mouse brain. Brain Res 1995; 705:345-8.

36. Kadota $\mathrm{Y}$, Inoue $\mathrm{K}$, Tokunaga R, Taketani S. Induction of peripheral-type benzodiazepine receptors in mouse brain following thioacetamide-induced acute liver failure. Life Sci 1996; 58:953-9.

37. Bélanger M, Desjardins P, Chatauret N, Rose C, Butterworth RF. Mild hypothermia prevents brain edema and attenuates up-regulation of the astrocytic benzodiazepine receptor in experimental acute liver failure. J Hepatol 2005; 42:694-9.

38. Leong DK, Therrien G, Swain MS, Butterworth RF. Densities of binding sites for the "peripheral-type" benzodiazepine receptor ligand 3H-PK11195 are increased in brain $24 \mathrm{~h}$ following portacaval anastomosis. Metab Brain Dis 1994; 9:267-73.

39. Ahboucha S, Butterworth RF. The neurosteroid system: implication in the pathophysiology of hepatic encephalopathy. Neurochem Inter 2008; 52:575-87.

40. Cagnin A, Taylor-Robinson SD, Forton DM, Banati RB. In vivo imaging of cerebral "peripheral benzodiazepine binding sites" in patients with hepatic encephalopathy. Gut 2006; 55:547-53.

41. Hazell AS, Desjardins P, Butterworth RF. Chronic exposure of rat primary astrocyte cultures to manganese results in increased binding sites for the 'peripheral type' benzodiazepine receptor ligand 3H-PK11195. Neurosci Lett 1999; 271:5-8.

42. Oh YJ, Francis JW, Markelonis GJ, Oh TH. Interleukin-1- $\beta$ and tumor necrosis factor- $\alpha$ increase peripheral-type benzodiazepine binding sites in cultured polygonal astrocytes. J Neurochem 1992; 58:2131-8.

43. Ahboucha S. Neurosteroids and hepatic encephalopathy: an update on possible pathophysiologic mechanisms. Curr Mol Pharmacol 2011; 4:1-13.

44. Butterworth RF. Neurosteroids in hepatic encephalopathy: Novel insights and new therapeutic opportunities. J Steroid Biochem Mol Biol 2015; doi. 10.1016/j.jsbmb.2015.11.006 [Epub ahead of print]

45. Rothstein JD, McKhann G, Guarneri P, Barbaccia ML, Guidotti A, Costa E. Cerebrospinal fluid content of diazepam binding inhibitor in chronic hepatic encephalopathy. Ann Neurol 1989; 26:57-62.

46. Butterworth RF, Tonon MC, Désy L, Giguère JF, Vaudry $\mathrm{H}$, Pelletier G. Increased brain content of the endogenous benzodiazepine receptor ligand, octadecaneuropeptide (ODN), following portacaval anastomosis in the rat. Peptides 1991; 12:119-25.
47. Hernández-Avila CA, Shoemaker WJ, Ortega-Soto HA. Plasma concentrations of endogenous benzodiazepine-receptor ligands in patients with hepatic encephalopathy: a comparative study. J Psychiatry Neurosci 1998; 23:217-22.

48. Laccetti M, Manes G, Uomo G, Lioniello M, Rabitti PG, Balzano A. Flumazenil in the treatment of acute hepatic encephalopathy in cirrhotic patients: a double blind randomized placebo controlled study. Dig Liver Dis 2000; 32:335-8.

49. Ahboucha S, Butterworth RF. Role of endogenous benzodiazepine ligands and their GABA-A-associated receptors in hepatic encephalopathy. Metab Brain Dis 2005; 20: 42537.

50. Belelli D, Lambert JJ. Neurosteroids: endogenous regulators of the GABA(A) receptor. Nature Rev Neurosci 2005; 6:565-75.

51. Ahboucha S, Desjardins P, Chatauret N, Pomier-Layrargues G, Butterworth RF. Normal coupling of brain benzodiazepine and neurosteroid modulatory sites on the GABA-A receptor complex in human hepatic encephalopathy. Neurochem Inter 2003; 43:551-6.

52. Ahboucha S, Coyne L, Hirakawa R, Butterworth RF, Halliwell RF. An interaction between benzodiazepines and neuroactive steroids at GABA A receptors in cultured hippocampal neurons. Neurochem Inter 2006; 48:703-7.

53. Ahboucha S, Talani G, Fanutza T, Sanna E, Biggio G, Gamrani $\mathrm{H}$, et al. Reduced brain levels of DHEAS in hepatic coma patients: significance for increased GABAergic tone in hepatic encephalopathy. Neurochem Inter 2012; 61:4853.

54. Rupprecht R, Holsboer F. Neuroactive steroids: mechanisms of action and neuropsychopharmacological perspectives. Trends Neurosci 1999; 22:410-6.

55. Yurdaydin C, Herneth AM, Puspok A, Steindl P, Singer E, Ferenci P. Modulation of hepatic encephalopathy in rats with thioacetamide-induced acute liver failure by serotonin antagonists. Eur J Gastroenterol Hepatol 1996; 8:667-71.

56. Wikell C, Bergqvist PB, Hjorth S, Apelqvist G, Bjork H, Bengtsson F. Brain monoamine output alterations after a single venlafaxine challenge in experimental hepatic encephalopathy. Clin Neuropharmacol 1998; 21:296-306.

57. Uzunova V, Wrynn AS, Kinnunen A, Ceci M, Kohler C, Uzunov DP. Chronic antidepressants reverse cerebrocortical allopregnanolone decline in the olfactory-bulbectomized rat. Eur J Pharmacol 2004; 486:31-4.

58. Desjardins P, Bélanger M, Butterworth RF. Alterations in expression of genes coding for key astrocytic proteins in acute liver failure. J Neurosci Res 2001; 66:967-71.

59. Bender AS, Norenberg MD. Effect of benzodiazepines and neurosteroids on ammonia-induced swelling in cultured astrocytes. J Neurosci Res 1998; 54:673-80.

60. Van Landingham JW, Cutler SM, Virmani S, Hoffman SW, Covey DF, Krishnan K, et al. The enantiomer of progesterone acts as a molecular neuroprotectant after traumatic brain injury. Neuropharmacology 2006; 51:1078-85. 